\title{
Development and characterization of biodegradable films from fermented yam (Dioscorea trifida L. f.)
}

\author{
Ana Cecília Nina Lobato', João Batista Dias Damaceno', Jaime Paiva Lopes Aguiar², Eyde \\ Cristianne Saraiva-Bonatto ${ }^{3}$, Charline Soares dos Santos Rolim ${ }^{3}$, Nilma de Souza \\ Fernandes ${ }^{4}$, Albejamere Pereira de Castro ${ }^{5}$, Carlos Victor Lamarão $0^{3^{*}}$ and Francisca das \\ Chagas do Amaral Souza ${ }^{2}$ \\ ${ }^{1}$ Faculdade de Ciências Agrárias, Universidade Federal do Amazonas, Manaus, Brazil. \\ ${ }^{2}$ Laboratório de físico-química de alimentos, Instituto Nacional de Pesquisas da Amazônia, Manaus, Brazil. \\ ${ }^{3}$ Departamento de Engenharia Agrícola e Solos, Universidade Federal do Amazonas, Manaus, Brazil. \\ ${ }^{4}$ Laboratório de Inovação Tecnológica no Desenvolvimento de Fármacos e Cosméticos, Universidade Estadual de \\ Maringá, Maringá, Brazil. \\ ${ }^{5}$ Departamento de Ciências Fundamentais e Desenvolvimento Agrícola, Universidade Federal do Amazonas, Manaus, \\ Brazil.
}

Received 13 June, 2019; Accepted 26 September, 2019

\begin{abstract}
The objective of this work was to develop and characterize biodegradable starch films at 14 and 21 days of fermentation, aiming to develop packaging with added value. For the extraction of starch, yam tubers were washed, crushed, filtered and fermented for 14 and 21 days, and then filtered and dehydrated. Water-starch-glycerol mixtures were prepared in a randomized design using a factorial scheme $(5 \times 2)$, with five concentrations of glycerol $(0,0.5,1.0,1.5$ and $2.0 \mathrm{~mL})$ using two durations (14 and 21 days) and 6 replicates. The analyzed parameters were thickness, density, solubility, sorption kinetics, humidity, scanning electron microscopy characteristics and color. Analysis of variance revealed significant difference at the $1 \%$ level for the interaction of fermentation time and glycerol concentration for the studied variables. Overall, a 21 day fermentation period gave better characteristics of density, humidity and color and the addition of plasticizer positively influenced the parameters studied.
\end{abstract}

Key words: Gelatinization, packaging, fermentation, starch.

\section{INTRODUCTION}

Growing demand for both higher quality food and shelf life extension, along with improving environmental management policies, has intensified the search for new methods and technologies to improve food conservation (Pereda et al., 2011; Almeida, 2014). Among these, packaging plays an important role for the food industry, as it must contain the product, and preserve and maintain its quality and safety, while acting as a barrier to factors responsible for deterioration (Coles, 2003). Growing concern about food safety, shelf life extension, costeffectiveness, consumer convenience and environmental problems has driven the development of both new packaging forms and new raw materials for its production (Coles, 2003). Currently, there is much interest in the

*Corresponding author. E-mail: victorlamarao@yahoo.com.br. Tel: +5592 9981478979.

Author(s) agree that this article remain permanently open access under the terms of the Creative Commons Attribution License 4.0 International License 
development of biodegradable packaging, which is designed to interact with the food, both prolonging shelf life and/or conferring desirable sensory and nutritional characteristics (Almeida et al., 2013).

Biodegradable packaging is a sustainable development alternative to petrochemical-based products, being generated from renewable resources it can also increase income for local farmers (Arenas, 2012). Developing the use of natural products in biodegradable packaging is of great interest to both industry and society in general, since it brings benefits for food-based industries and the environment (Dantas et al., 2015).

In addition, the use of packaging based on nationallysource materials in packaging manufacture enhances the profitability of Brazilian agroindustry (Reis, 2011). Among the raw materials used in the preparation of biopolymers, the potential of starch, either as pulp or granules, as a source biodegradable films has been widely studied, as it is renewable, cheap and widely available (Cano et al., 2014; Santos, 2015). It can be obtained from a variety of plant sources, including cereals, roots and tubers, as well as seeds and fruit pulp, with the derived materials having different physical, chemical and functional characteristics depending on their origin (Mali el al., 2010).

Among the various sources of starch is the yam, a member of the family Dioscoreaceae and a producer of starch-rich, high-energy and nutritious food tubers (Oliveira, 2002). These contain between 28.1 and $29.5 \%$ dry matter, of which 70.3 to $79.5 \%$ is starch, 1.7 to $4.3 \%$ is reducing sugars, 0.6 to $2.9 \%$ fibers, and 4.6 to $7.1 \%$ proteins (Leonel and Cereda, 2002). In addition, the plant has known anti-microbial, diuretic and energizing properties (Ramos-Escuredo et al., 2010).

Dioscorea yams are the fourth most important tuber/root crop in the world, lying only behind potato (Solanum tuberosum L.), cassava (Manihot esculenta Crantz) and sweet potato (Ipomoea batatas L.). However, because it is not included in the list of "noble" crops, the genus is rarely included in agricultural policies, government projects, economic and financial plans for exportable monocultures, and even if the area cultivated is more than one million hectares worldwide. In Brazil, this yam is typically a smallholder crop used for direct consumption or local sale (Leonel and Cereda, 2002). Thus, with the aim of adding value to the by-products of yam culture, the objective of this study was to develop and characterize biodegradable films of starch derived from this yam after 14 and 21 days of fermentation.

\section{MATERIALS AND METHODS}

\section{Study area}

Experiments were conducted at the Food Chemistry and Physics Laboratory, National Amazon Research Institute $\left(3^{\circ} 5^{\prime} 29 " S\right.$, $\left.59^{\circ} 59^{\prime} 37^{\prime \prime W}\right)$, and at the Vegetable-Origin Products Technology Laboratory at the Amazonas Federal University $\left(3^{\circ} 5^{\prime} 28^{\prime \prime S}\right.$, $59^{\circ} 57^{\prime} 57^{\prime \prime W}$ ) in Manaus, Amazonas State, Brazil.

\section{Sample preparation}

Artisanal techniques adapted from the methods described by Leonel and Cereda (2002), and Nunes et al. (2010) was used in the preparation of the mash to be fermented. The tubers were cleaned to remove soil and foreign bodies, peeled, washed, and sectioned into smaller pieces. The filtrate was fermented for 14 and 21 days, respectively, with water changed every two days at a temperature of $40^{\circ} \mathrm{C}$. At the end of the fermentation period, the supernatant was discarded and the fermented material dehydrated at room temperature, then sieved, crushed and stored in plastic pots.

\section{Physico-chemical analysis of yam tuber filtrate}

Physico-chemical analysis was conducted in triplicate, following the methods of the Instituto Adolfo Lutz- IAL (2008) and the Associação de Químicos Analíticos Oficiais- AOAC (1980).

\section{Moisture content}

This was determined following IAL (2008) protocol 012/IV. Samples were dried in a vacuum kiln at $105^{\circ} \mathrm{C}$ for $24 \mathrm{~h}$.

\section{Ash content}

This was determined by incineration, following protocol 923.03 of AOAC (1980) in a crucible at $550^{\circ} \mathrm{C}$ until calcination was complete.

\section{Mineral content}

This was determined by atomic absorption spectrometry, following protocol 394/IV of IAL (2008), and the guidelines in Varian (2000). Samples were prepared in a MARS-Xpress microwave digester (CEM Corporation, MD-2591), with organic material mineralized with concentrated nitric acid sequentially diluted with deionized water. Readings were made directly from diluted solutions in an atomic absorption photo spectrometer (Spectra AA, model 220, FS, Varian 2000), using manufacturer-specified light sources. The analyzed elements were: $\mathrm{Ca}, \mathrm{K}, \mathrm{Na}, \mathrm{Mg}, \mathrm{Fe}, \mathrm{Zn}, \mathrm{Mn}$ and $\mathrm{Cu}$.

\section{Lipids}

Lipid content was determined following IAL (2008) protocol 032/IV, with samples obtained via a Soxhlet extractor with petroleum ether.

\section{Protein}

Protein content was determined by the micro-Kjedhal method, following AOAC (1980) protocol 926.86, using a 6.25 conversion factor.

\section{Crude fibre}

For the quantification of soluble and insoluble digestible fibre, the enzymatic-gravimetric method given in IAL (2008) protocol 046/IV was used. The proportion of total fibre was determined by adding the values obtained for the soluble and insoluble fractions.

\section{Carbohydrates}

Carbohydrate content was determined following IAL (2008) for 
Table 1. Formulation of films from fermented yam mash filtrate.

\begin{tabular}{cccc}
\hline Sample & Starch $(\mathbf{g})$ & Distilled water $(\mathbf{m L})$ & Glycerol $(\mathbf{m L})$ \\
\hline I & 1.125 & 30.0 & 0.00 \\
II & 1.125 & 30.0 & 0.50 \\
III & 1.125 & 30.0 & 1.00 \\
IV & 1.125 & 30.0 & 1.50 \\
V & 1.125 & 30.0 & 2.00 \\
\hline
\end{tabular}

cereals, starches and soya extracts, using centesimal differences of the sum of moisture, ash, lipids and dietary fiber.

Starch

Starch content was determined following protocol AOAC 996.11 modified by Water et al. (2005). Total starch was determined by subtracting the sum of the available starch and all other non-starch residuals from total weight.

\section{pH}

Hydrogenation potential was determined following protocol 017/IV of IAL (2008) by direct reading of the supernatant liquid.

\section{Soluble achohol acidity}

This was determined following IAL (2008) protocol 415/IV. Samples were titrated with $0.1 \mathrm{~mol} \mathrm{NaOH}$ until rose coloration appeared.

\section{Biodegradable film production}

Films were made following a method described by Dantas et al. (2015) and Lorotonda (2002). Water-starch-glycerol mixtures were prepared by varying the glycerol concentration in relation to the starch-water mixture (Table 1). A randomized factorial scheme (5x2) design was used, with five concentrations of glycerol $(0.0,0.5$, $1.0,1.5$ and $2.0 \mathrm{~mL}$ ), two fermentation durations (14 and 21 days) and 6 replicates, a total of 60 experimental units.

The mixtures were heated to boiling, and the temperature maintained at about $185^{\circ} \mathrm{C}$ until, under constant stirring, a gel formed. This was then spread on $8 \mathrm{~cm}^{2}$ petri dishes, and oven cooled at $40^{\circ} \mathrm{C}$ for $48 \mathrm{~h}$

\section{Characterizing the films}

The starch films were tested for thickness, solubility, moisture, density, sorption kinetics, scanning electron microscopy characteristics and color.

\section{Thickness}

Thickness was measured with digital calipers at 10 randomized points across the surface of each film (Batista, 2005)

\section{Solubility in water}

The solubility tests were by difference of the initial and final mass of the sample (Matta Júnior et al., 2011).

\section{Scanning electron microscope analysis of biofilm structure}

The films were plated with gold and surface structure visualized with a scanning electron microscope (FEI, model QUANTA 250).

\section{Density}

Density was determined by the difference between the final and the initial mass in a desiccator (Müller et al., 2008).

\section{Water sporption and humidity kinetics}

Moisture sorption kinetics was determined by weighing at successive time intervals until a constant weight was obtained (Mali et al., 2005).

\section{Optical properties: Color}

Color was determined using a portable color photospectrometer (Miniscan XE, Hunter Lab, Reston, Virginia, USA)(Hunterlab, 1997).

\section{Statistical analysis}

Analyzes of variance (ANOVA) and Tukey's test were performed to compare means, with significance level at $5 \%$. Calculations were performed using Assitat version 7.7.

\section{RESULTS}

\section{Physico-chemical analysis of yam tuber filtrate}

The final product was a fine, odorless powder with color varying according to the number of days of fermentation: At 14 days it had a pink coloration, while samples from 21 days fermentation were whitish (Figure 1). Table 2 gives mean values and standard deviations of the physicochemical composition of the fermentates studied.

At the $1 \%$ probability level, Tukey tests showed that ash, crude protein, lipids and $\mathrm{pH}$ had statistically different values $(p \leq 0.01)$ for studied fermentates in relation to the fermentation period. Highest average values were found from the 21 days fermentation sample (Table 2).

The variation in $\mathrm{pH}$ between the samples is worthy of comment: After 14 days of fermentation, the starch-rich fermentate was slightly acidic, however, after 21 days the $\mathrm{pH}$ has risen dramatically, so that the samples were 


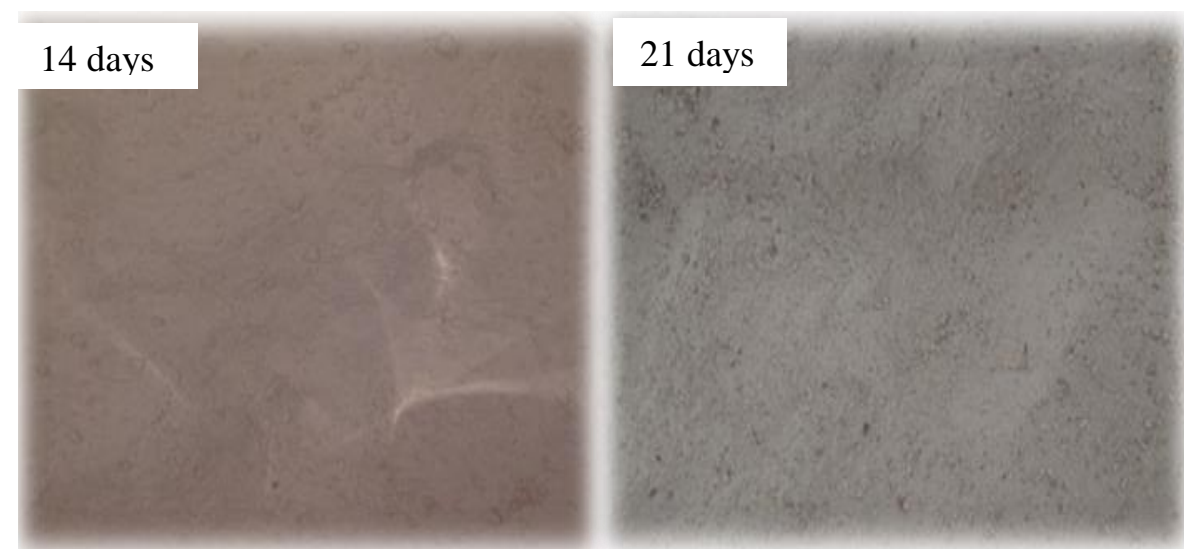

Figure 1. Character starch at 14 days and 21 days of fermentation.

Table 2. Mean values and standard deviations of the physico-chemical parameters analysed for cushcush yam fermentates for two different fermentation durations.

\begin{tabular}{lcc}
\hline \multirow{2}{*}{ Parameter $^{*}$} & \multicolumn{2}{c}{ Sample } \\
\cline { 2 - 3 } & 14 days fermemtation & 21 days fermentation \\
\hline Dry material & $77.61 \pm 3.62^{\mathrm{a}}$ & $81.38 \pm 2.88^{\mathrm{a}}$ \\
Moisture (\%) & $22.39 \pm 3.62^{\mathrm{a}}$ & $18.62 \pm 2.88^{\mathrm{a}}$ \\
Ash (\%) & $0.05 \pm 0.01^{\mathrm{b}}$ & $0.31 \pm 0.01^{\mathrm{a}}$ \\
Lipídeos (\%) & $0.21 \pm 0.06^{\mathrm{b}}$ & $0.55 \pm 0.22^{\mathrm{a}}$ \\
Crude Protein (\%) & $0.79 \pm 0.01^{\mathrm{b}}$ & $0.99 \pm 0.10^{\mathrm{a}}$ \\
Total Fibre (\%) & $1.02 \pm 0.07^{\mathrm{a}}$ & $1.16 \pm 0.06^{\mathrm{a}}$ \\
Carbohydrates (\%) & $75.55 \pm 3.66^{\mathrm{a}}$ & $78.38 \pm 2.99^{\mathrm{a}}$ \\
pH & $6.00 \pm 0.30^{\mathrm{b}}$ & $8.73 \pm 1.56^{\mathrm{a}}$ \\
Soluble Alcohol Acidity (\%) & $1.13 \pm 0.12^{\mathrm{a}}$ & $1.27 \pm 0.12^{\mathrm{a}}$ \\
Starch & $87.35 \pm 0.11^{\mathrm{a}}$ & $87.32 \pm 0.16^{\mathrm{a}}$ \\
\hline
\end{tabular}

*Means of 3 samples \pm standard deviations. CV\% = 15.96 (Moisture); DMS $=7.42399$ (Moisture); CV\% $=6.86$ (Ash); DMS = 0.02743 (Ash); CV\% = 29.77 (Lipids); DMS = 0.2549 (Lipids); CV\% = 5.62 (Crude Proteín); DMS $=0.11336$ (Crude Proteín); $C V \%=6.19$ (Total Fibre); $D M S=0.15305$ (Total Fibre); $C V \%=4.34$ (Carbohydrate); DMS = 7.58009 (Carbohydrate); $C V \%=3.07(\mathrm{pH}) ; D M S=0.51266(\mathrm{pH}) ; C V \%=9.69$ (Titratable acidity); DMS $=0.2636$ (Titratable acidity); $C V \%=0.17$ (Starch); $D M S=0.3368$ (Starch). Means followed by the same letters do not differ statistically from each other (Tukey test, $1 \%$ significance).

becoming alkaline. In relation to mineralogical analysis, fermentates had high mineral contents, of which potassium, iron and magnesium were present in greatest quantity (Table 3).

\section{Film extraction (drying and removal)}

Films of glycerol plastified starch, were homogeneous, continuous, and without fractures or ruptures. Handling qualities of the films were excellent or good in most treatments, except for films with 1.5 and $2.0 \mathrm{~mL}$ of glycerol (Treatments 4 and 5), which were difficult to detach from the petri dish surfaces without tearing. However, after removal, all films could all be manipulated without any risk of rupture.

\section{Analysis of density, solubility, moisture content, thickness and kinetics}

There was a significant difference in the interaction between the fermentation time and the glycerol concentration at $1 \%$ for the parameters thickness, solubility, density and humidity (Table 4).

Thickness data showed differences in thickness between films for all glycerol concentrations for mash derived from 14-day fermentate. However, for 21-day fermentate, only treatment 1 ( $0 \mathrm{~mL}$ of glycerol) differed significantly in thickness from the other four treatments, these being indistinguishable.

For films derived from 14-day fermentate, regression analysis was significant $(p<0.01)$, indicating that when glycerol concentration increases, the yam-based film 
Table 3. Mean concentration of macro- and micro-minerals $(\mathrm{mg} / 100 \mathrm{~g})$.

\begin{tabular}{ccc}
\hline Mean mineral concentration & \multicolumn{2}{c}{ Sample } \\
\cline { 2 - 3 }$(\mathbf{m g} / \mathbf{1 0 0} \mathbf{~})^{*}$ & $\mathbf{1 4}$ days fermemtation & 21 days fermentation \\
$\mathrm{Ca}$ & $0.10 \pm 0.01$ & $0.10 \pm 0.01$ \\
$\mathrm{Mg}$ & $1.87 \pm 0.04$ & $3.37 \pm 0.07$ \\
$\mathrm{~K}$ & $64.99 \pm 2.64$ & $87.49 \pm 0.86$ \\
$\mathrm{Na}$ & $0.00 \pm 0.00$ & $0.00 \pm 0.00$ \\
$\mathrm{P}$ & $0.00 \pm 0.00$ & $0.00 \pm 0.00$ \\
$\mathrm{Mn}$ & $0.00 \pm 0.00$ & $0.02 \pm 0.01$ \\
$\mathrm{Cu}$ & $0.00 \pm 0.00$ & $0.55 \pm 0.74$ \\
$\mathrm{Zn}$ & $1.00 \pm 0.21$ & $1.12 \pm 0.07$ \\
$\mathrm{Fe}$ & $1.04 \pm 0.02$ & $1.74 \pm 0.11$ \\
\hline
\end{tabular}

*Means of 3 samples \pm standard deviations.

Table 4. Values for thickness, solubility, density and moisture content of yam-derived starch biofilms following 14 and 21 days fermentation with the addition of either $0 \mathrm{~mL}(\mathrm{~T} 1), 0.5 \mathrm{~mL}$ (T2), $1.0 \mathrm{~mL}$ (T3), $1.5 \mathrm{~mL}$ (T4) and $2.0 \mathrm{~mL}$ (T5) of glycerol.

\begin{tabular}{|c|c|c|c|c|c|c|}
\hline \multirow{2}{*}{ Parameter } & \multirow{2}{*}{$\begin{array}{c}\text { Fermentation } \\
\text { duration (days) }\end{array}$} & \multicolumn{5}{|c|}{ Glycerol concentration (mL) } \\
\hline & & $0.0(\mathrm{~T} 1)$ & 0.5 (T2) & $1.0(\mathrm{~T} 3)$ & $1.5(\mathrm{~T} 4)$ & 2.0 (T5) \\
\hline \multirow{2}{*}{ Thicknes (mm) } & 14 & $0.23^{\mathrm{aE}}$ & $0.29^{b D}$ & $0.35^{\mathrm{aC}}$ & $0.41^{\mathrm{aB}}$ & $0.46^{\mathrm{aA}}$ \\
\hline & 21 & $0.22^{\mathrm{aB}}$ & $0.34^{\mathrm{aA}}$ & $0.35^{\mathrm{aA}}$ & $0.34^{\mathrm{bA}}$ & $0.34^{\mathrm{bA}}$ \\
\hline \multirow{2}{*}{ Solubility (\%) } & 14 & $12.98^{\mathrm{bE}}$ & $46.98^{\mathrm{bD}}$ & $61.71^{\mathrm{aC}}$ & $70.7^{\mathrm{aB}}$ & $74.29^{\mathrm{bA}}$ \\
\hline & 21 & $49.84^{\mathrm{aE}}$ & $52.70^{\mathrm{aD}}$ & $63.31^{\mathrm{aC}}$ & $69.70^{\mathrm{aB}}$ & $76.92^{\mathrm{aA}}$ \\
\hline \multirow{2}{*}{ Density $\left(\mathrm{g} / \mathrm{cm}^{2}\right)$} & 14 & $0.10^{\mathrm{aC}}$ & $0.12^{\mathrm{aB}}$ & $0.18^{\mathrm{aA}}$ & $0.17^{\mathrm{aA}}$ & $0.18^{\mathrm{bA}}$ \\
\hline & 21 & $0.097^{\mathrm{aD}}$ & $0.12^{\mathrm{aC}}$ & $0.15^{\mathrm{bB}}$ & $0.17^{\mathrm{aB}}$ & $0.26^{\mathrm{aA}}$ \\
\hline \multirow{2}{*}{ Moisture (\%) } & 14 & $13.53^{\mathrm{ac}}$ & $24.17^{\mathrm{bB}}$ & $42.72^{\mathrm{aA}}$ & $43.49^{\mathrm{aA}}$ & $42.53^{\mathrm{bA}}$ \\
\hline & 21 & $11.80^{\mathrm{bE}}$ & $26.74^{\mathrm{aD}}$ & $41.86^{\mathrm{aC}}$ & $43.84^{\mathrm{aB}}$ & $45.83^{\mathrm{aA}}$ \\
\hline
\end{tabular}

* Distinct letters in the columns (lower case letters) and rows (upper case letters) differ significantly from each other by the Tukey test

becomes thicker (Figure 2).

For solubillity, the studied yam-derived starch films were after $24 \mathrm{~h}$ water immersion, semi-intergal in shape, and very flexible and foldable. Films derived from both 14 and 21-day fermentate showed gradual increases in solubility as a function of glycerol addition. Biofilms lacking any glycerol had low solubility, due to the loss of water during the drying process, which made them more rigid and brittle. However, as glycerol was added, the films became more soluble gradually reaching an average of $75.57 \%$ water.

The humidity of the films showed a significant difference in the interaction between the fermentation time factors and glycerol concentration at $1 \%$ level. For films derived from 14 days of fermentation there were statistical differences between treatments 1 and 2 and all other treatments (which were statistically identical to each other). However for 21 day-derived films there were differences between films at concentrations (Table 4).

Regression analysis was significant $(p<0.05)$ for both 14 and 21 day-derived films, indicating a tendency for films to increase in humidity as a function of the addition of glycerol. As shown in Figure 2, the addition of $1 \mathrm{~mL}$ of glycerol results in an increase of $33.29 \%$ (14 days) and $34.02 \%$ (21 days) in film moisture content (Figure 3).

The density of the starch films differed statistically $(p$ $<0.01$ ) between the formulations with $0 \mathrm{~mL}$ (T1) and 0.5 $\mathrm{mL}$ (T2) of glycerol in film derived from 14-day and 21day fermentates. The regression in Figure 4 indicates a clear trend for progressive density increase to occur as a function of glycerol addition.

There were no significant differences between the fermentation time and the interaction for water sorption kinetics. However, glycerol content influenced the water adsorption process, so that treatment 3 showed the highest water adsorption value (Table 5).

\section{Scanning electron microscope}

The films shown in the photomicrographs in Figures 5 and 6 appear as an extensive and amorphous mass, with 


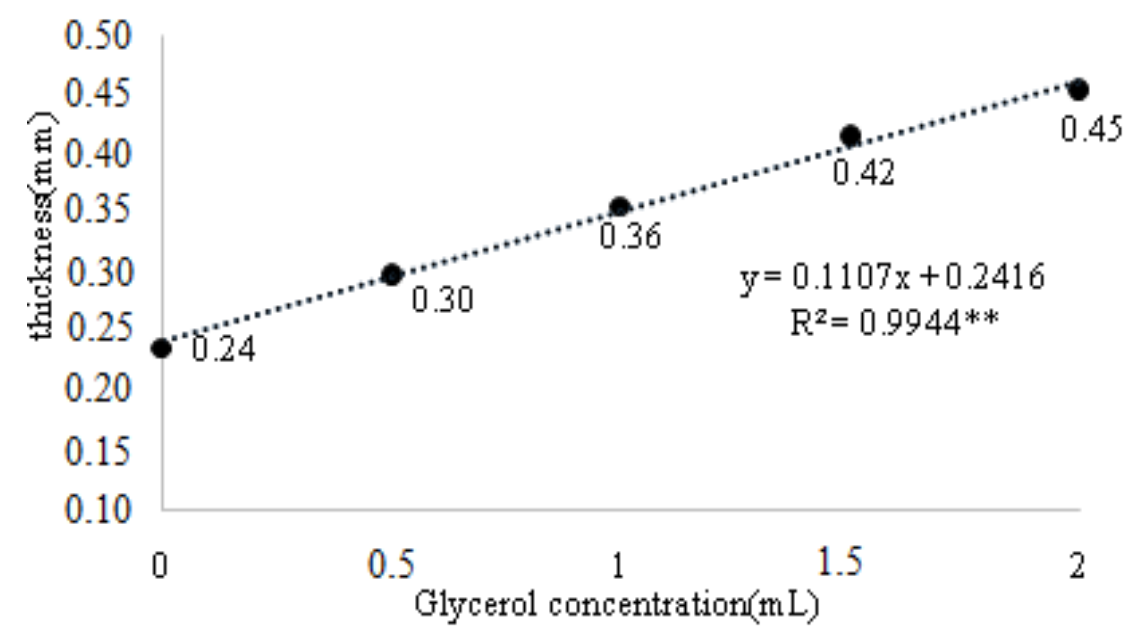

Figure 2. Yam-starch film thickness as a function of glycerol concentrations after 14 days of fermentation.
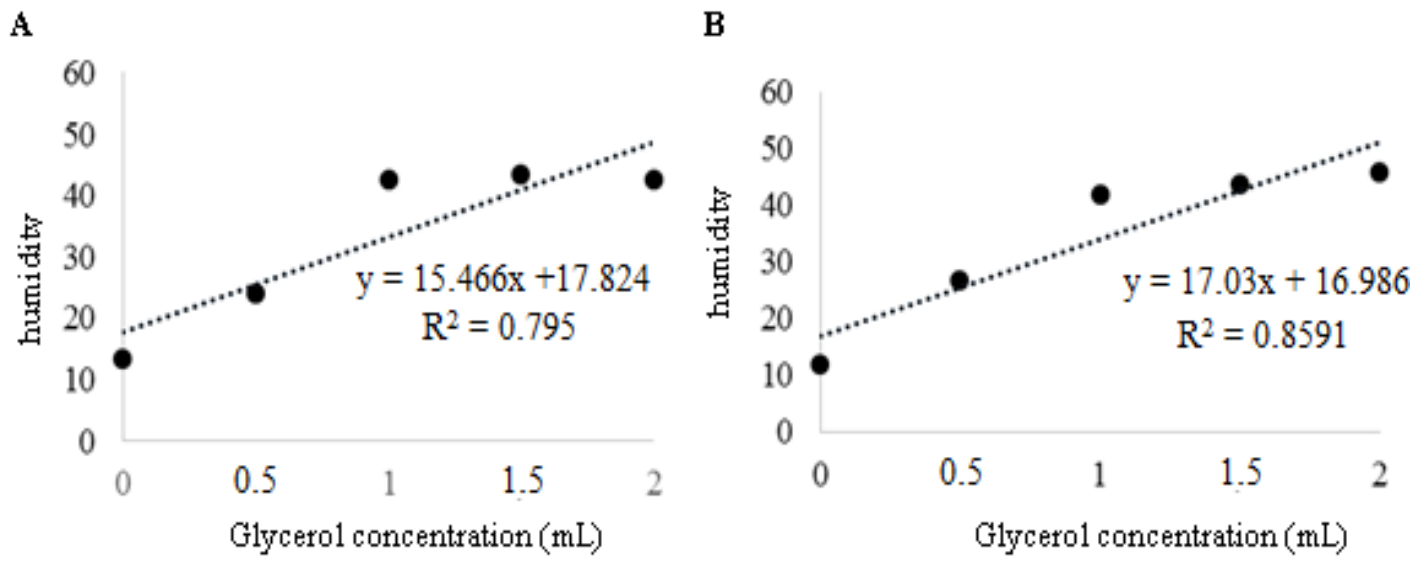

Figure 3. Moisture content of films as a function of glycerol concentration for films derived from (A) 14- and (B) 21-day fermentation.

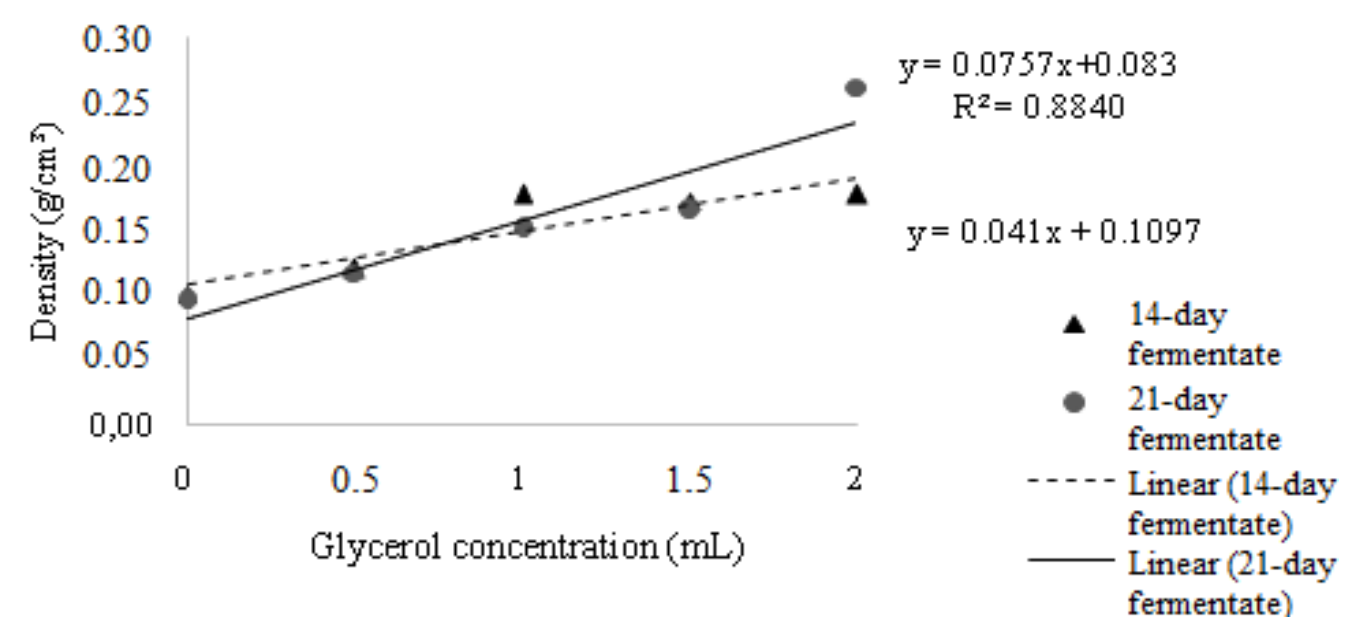

Figure 4. Density of films as a function of glycerol concentration for films derived from 14- and 21day fermentation. 
Table 5. Means of sorption kinetics values as a function addition of glycerol to biodegradable films.

\begin{tabular}{cl}
\hline Glycerol concentration $(\mathrm{mL})$ & Mean \\
\hline $0.0(\mathrm{~T} 1)$ & $27.83^{\mathrm{c}}$ \\
$0.5(\mathrm{~T} 2)$ & $17.23^{\mathrm{d}}$ \\
$1.0(\mathrm{~T} 3)$ & $34.58^{\mathrm{a}}$ \\
$1.5(\mathrm{~T} 4)$ & $33.38^{\mathrm{b}}$ \\
$2.0(\mathrm{~T} 5)$ & $32.98^{\mathrm{b}}$ \\
\hline
\end{tabular}

$\mathrm{CV} \%=3.23 ; \mathrm{dms}=1.08873$. The means followed by different letters differ statistically between each other.

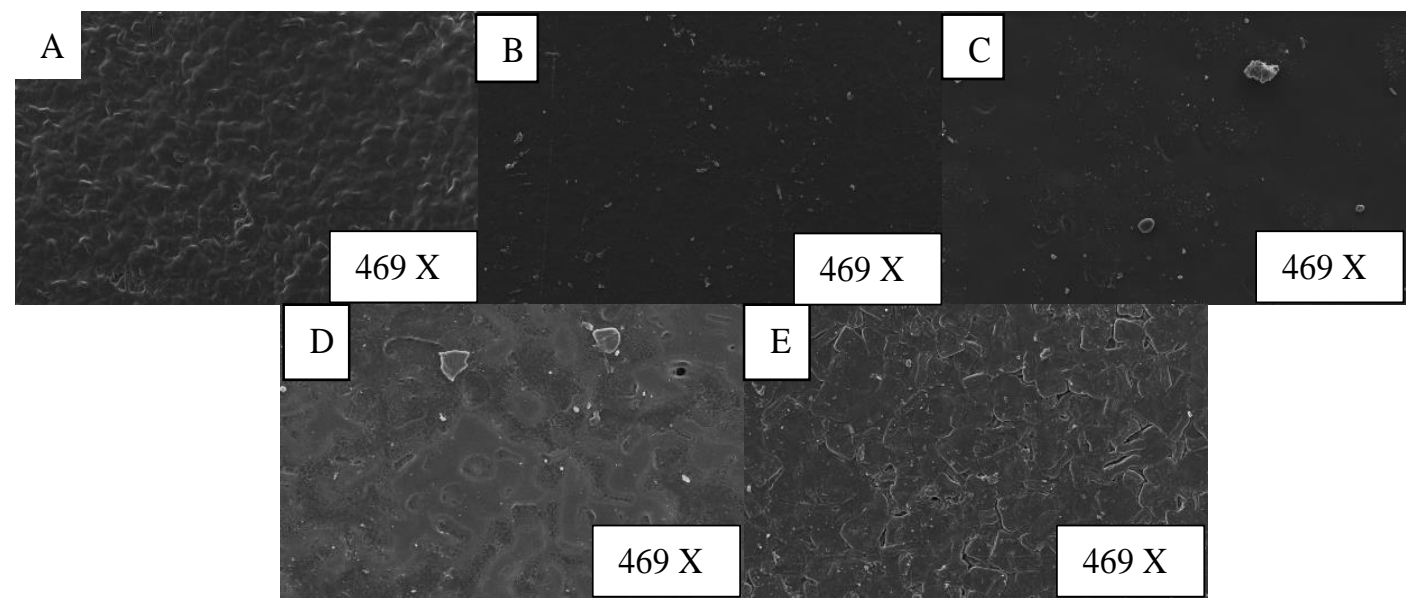

Figure 5. Scanning electron micrograph (SEM) at $300 \mu \mathrm{m}$ of films from 14-day fermentate: $\mathrm{A}$ ( $0 \%$ glycerol), B (0.5\% glycerol), C (1.5\% glycerol), D (2.0\% glycerol), E (2.5\% glycerol).

the presence of rounded depressions.

\section{Color}

Evaluating the luminosity parameters for the glycerol concentration and the fermentation time, in which $\mathrm{L}_{0}{ }^{*}$ represents the results of standard films made from cassava starch and $L^{*}$ the results of yam starch films, a proximity among the values indicate that there were variations between cassava-derived (standard) and yamderived films. However, when comparing the yam-derived samples with each other, there was little variations between them, except for films from treatment 1 made from 14-day fermentate (Table 6).

The intensity of these variations $(\Delta \mathrm{E})$ however varies between films. For films derived from 14-day fermentate those with pure starch and with addition of $1.5 \mathrm{~mL}$ of glycerol showed more intense variation in color. However, for films derived from 21-day fermentate, those to which glycerol had been added showed more intense variations than films without glycerol.

\section{DISCUSSION}

\section{Physical-chemical analysis of yam starch}

No legal classification exists for yam fermentate, and no references were found in the literature for its physical and chemical characteristics. Consequently, the data was compared with existing studies on cassava. Moisture levels for both the 14-day and 21-day fermentation samples were higher than those reported by Aquino et al. (2011) and de Reis et al. (2010) for yam tuber starch (11.9 and $7.61 \%$, respectively). These values would not comply with regulations for moisture content operating in Brazil (ANVISA RDC $n^{\circ} 263$ of 2005 September 22, which ratified the Technical Regulation for cereals, starches, flours and vegetable-powders).

Variation in moisture levels could be related to the artesanal methods used to prepare the base material, as well as the drying time and the conditions under which drying occurred. Maieves (2010), studying the composition of different tubers as a function of part of the year in which they were collected, posited that moisture 


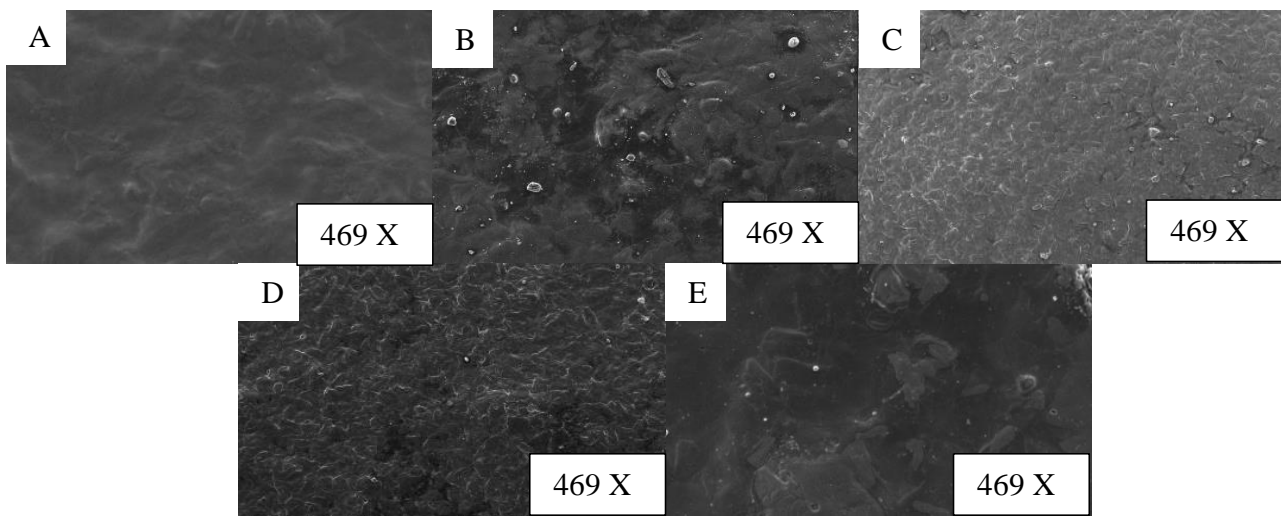

Figure 6. Scanning electron micrograph (SEM) at $300 \mu \mathrm{m}$ of films from 14-day fermentate: A $(0 \%$ glycerol), B (0.5\% glycerol), C (1.5\% glycerol), D (2.0\% de glycerol), E (2.5\% glycerol).

Table 6. Photospectometric analysis of yam-derived starch filmes as a function of fermentation time and glycerol concentration.

\begin{tabular}{|c|c|c|c|c|c|c|c|c|}
\hline Fermentation time (Days) & Glycerol concentration (mL) & $\mathrm{L}_{0}{ }^{*}$ & $\mathbf{L}^{*}$ & $a_{0}{ }^{*}$ & $a^{*}$ & $\mathrm{~b}_{0}{ }^{*}$ & $b^{*}$ & $\Delta \mathrm{E}$ \\
\hline 14 & 0.0 & 34.07 & 29.72 & 0.04 & -0.27 & -0.46 & -1.6 & 4.51 \\
\hline 14 & 0.5 & 34.07 & 32.73 & 0.04 & 0.33 & -0.46 & 0.26 & 1.57 \\
\hline 14 & 1.0 & 34.07 & 32.61 & 0.04 & 0.7 & -0.46 & 0.63 & 1.97 \\
\hline 14 & 1.5 & 34.07 & 32.25 & 0.04 & 0.51 & -0.46 & 0.26 & 2.03 \\
\hline 14 & 2.0 & 34.07 & 33.94 & 0.04 & 0.9 & -0.46 & 1.2 & 1.92 \\
\hline 21 & 0.0 & 34.07 & 33.48 & 0.04 & 0.18 & -0.46 & 0.37 & 1.05 \\
\hline 21 & 1.5 & 34.07 & 31.92 & 0.04 & 0.1 & -0.46 & 0.69 & 2.44 \\
\hline 21 & 2.0 & 34.07 & 31.76 & 0.04 & -0.05 & -0.46 & -0.06 & 2.35 \\
\hline
\end{tabular}

Initial $\left(\mathrm{L}_{0}{ }^{*}\right)$ and final $\left(\mathrm{L}^{*}\right)$ luminosity, chromatic parameters control $\mathrm{a}^{*}$ and $\mathrm{b}^{*}$ initial $\left(\mathrm{a}_{0}{ }^{*}\right.$ and $\left.\mathrm{b}_{0}{ }^{*}\right)$ and final $\left(\mathrm{a}^{*}\right.$ and $\left.\mathrm{b}^{*}\right)$ and colour alteration $(\Delta \mathrm{E})$.

content might vary in line with soil water content, since the months with highest water availability were also those with greatest tuber moisture content $(43.12 \%)$. Similar values were reported by Dantas et al. (2010) (45.89\%), and by Alves et al. (2005) (55.54\%). Accordign to Diniz (2006), there are no published studies to show that extreme moisture contents negatively influence the technological properties of bitter manioc powder. There may be some exaggeration about the risks that moisture contents above $18 \%$ could cause (Cereda and Vilpoux, 2002). According to Maeda (1999), the water content fermented cassava starch ranges from 0.40 to 0.60 , so it should be possible to change the limits required by the legislation.

Ash levels from 21-day fermentate were higher than those reported both for yam by Vilpoux et al. (2002) $(0.22 \%)$, and for cassava by Cereda et al. (2001) and Aquino et al. (2016) (both 0.13 to $0.25 \%$ ). However, the proportions encountered here were lower than those reported by Reis et al. (2010) for yam (0.92\%). Ash values reported by Silva et al. (2012) for cassava flour
$(0.08 \%)$ were similar to those found in the current study for material derived from 14 day fermentate.

Lipid values (Table 2) were lower than those reported by Reis et al. (2010) $(0.64 \%)$, but greater than those of Silva et al. (2006) $(0.06 \%)$ for yam, and resembling those for cassava from the studies of Pereira et al. (1999) $(0.26 \%)$ and Marcon et al. (2006) (0.18 to $0.21 \%$ ). Ladeira and Pena (2011) found that low lipid levels in fermentation-derived flours were caused by their elimination during product processing, so that the repeated washings in the preparation methodology of the current study may explain the low values reported here.

Obtained crude protein values (Table 2) were lower than those reported by Aquino et al. (2011) (4.88 to 4.99\%) and Daiuto and Cereda (2003) (4.19\%). According to these authors, elevated crude protein values may be associated with nitrogen residues resulting from the breakdown of mucopolysaccharides (mucilage). An analysis of proteins in flour from three varieties of bitter manioc by Ladeira and Pena (2011) found values similar to those in the current study (0.20 to $1.06 \%)$, and much 
higher than those reported by Cereda and Vilpoux (2002), for sweet yam (Dioscorea sp.) flour (0.09\%). According to Vieira et al. (2010) and Pereira et al. (1999) a reduction in the protein content can be attributed to the loss of water-soluble proteins water soluble during raw material processing.

Brazilian legislation has no established guidelines for percentage of total fibre. However, it is notable that, with the exception of the study by Dias and Leonel (2006) ( 0.57 to $2.75 \%$ ), the values obtained by the current study were greater than any of bitter manioc flour (Reis et al., 2010: 0.17\%; 0.02\%; Vieira et al., 2010: 0.28\%; Leonel et al., 2004: 0.74\%; Fiorda et al., 2013: 0.61\%; Trombini et al., 2013: 0.39\%; Maciel et al., 2013: 0.30\%) (Table 3). Fiorda et al. (2013) and Tromboni et al. (2013) found that different crude fibre levels can depend on the species studied, as well as the time of planting, the soil type, and the climatic conditions under which the plant grew, and the methods by which the sample was extracted. However, although the values found here were higher than those of the authors cited, the analyzed fermentates had low fiber contents based on the classification of Mattos and Martins (2000) (below $2.4 \mathrm{~g}$ fibers/100 g).

During the fermentation process, it was noted that a reduction in the level of carbohydrates was associated with increased moisture content (Table 2), while centesimal analysis revealed high carbohydrate levels in the yam fermentate. Mean carbohydrate values were similar to those reported by de Ferreira (2014) for saffron starch $(79 \%)$, thus agreeing with the data of de Luna et al. (2013) for cassava (78.55), these being greater than those reported by Nascimento et al. (2013) for sweet potato (65.18\%) and Holland and Oliveira (2015) cassava-derived gum (70.02\%). However, these values are lower than those reported by Rocha et al. (2012) wolf-tomato flour (Solanum lycocarpum) $(84.99 \%)$ and Fiorda et al. (2013) for cassava starch $(85.53 \%)$.

The $\mathrm{pH}$ values from samples classified as slightly acid $(\mathrm{pH}>4.5)$ (Tupinamba and Souza, 2010). Similar values have been reported by Silva et al. (2012) (6.03 to 6.21), Dias and Leonel (2006) (4.24 to 6.10) and Ladeira and Pena (2011) (7.09) for cassava flour. The variation in $\mathrm{pH}$ values encountered in the current study is explained by Cereda (1987) and Ascheri and Vilela (1995) who observed that natural fermentation process result in a lack of product uniformity, even in the same species in the same environment, due to the different phases of the microbial growth and acid production, that occur when there is no quality control. Contrary to expectations no rapid falls occurred after the first two days of fermentation, after which low values were reached which continued until the end of the fermentation period. $\mathrm{pH}$ at the end of 21 days was alkaline, which can be explained by the species used, for which both the fermentation processes and the microorganisms involved in fermentation are not known, so requiring further specific studies for effective culture.
Brazilian legislation classifies vegetable-derived flours as sweet and bitter, based on their titratable acidity (BRASIL, 1978), as a result all the material in this study is classified as "bitter" (Table 3 ). The acidity results are similar to those reported by Leonel et al. (2004) physicalchemical characterization of starches $(1.05 \%)$, and with those of Luna et al. (2013) for cassava (1.4\%), and higher than those reported by Ladeira and Pena (2011) ( 0.89 to $0.96 \%)$. The increase in acidity between 14 and 21 days of fermentation most likely occurred as a result of prolonged exposure of the material to high ambient temperatures and the extension of the fermentation period (Tupinamba and Souza, 2010). It is interesting to note that the values found in our study were lower than those of Machado et al. (2010) (3.12\%), Garcia et al. (2014) (2.16 to 6.36\%), Machado et al. (2013) (3.12\%), Aquino et al. (2016) (1.66 to 7.05\%), Dias and Leonel (2006) with values between 2.08 and $7.4 \%$ and Reginatto et al. (2009) means between 2.5 and $4.0 \%$ for cassava.

Silva et al. (2006) reported that elevated acidity levels are related to increased availability of carboxil groups, which are probably the result of acid residues derived from the degradation of the macromolecules that make up the starch. Variation in acidity is explained by Cereda and Lima (1981), who noted that a level of titratable acidity is characteristic of the natural fermentation used to create such acid flours. The authors encountered a great variety of values, which were explained not only by the percentage of acidic compounds present, but also by their nature, since acidic character may vary depending on the size of the chain and the number of carboxylates.

The starch values encountered here meet those stipulated by ANVISA RDC $n^{\circ} 263$ of 2005 September 22. Such results are similar to those of Reis et al. (2010) and Cereda and Vilpoux (2002) also from yam (88.58 and $83.06 \%$, respectively). However, values are lower than those for cassava, where starch values of over $90 \%$ have been reported by Ladeira and Pena (2011) (94.79\%), Silva et al. (2012) (93.47 to 97.46\%), Oliveira (2011) (90.48 to 94.7\%) and Peroni (2003) (98.94 to 99.58\%). The purity of such starches is related to their chemical composition, and the low levels of proteins, lipids and ash, and absence of those protein that adhere to the starch granules is desirable (Oliveira, 2011). The quantity of constituents depends on the composition of the plants used and the methods of extraction, which is pertinent as the physical-chemical composition of yam is, following the classification of Peroni (2003), considered one of the lowest for non-starch substances, and one of the highest for starch, both in terms of quantity and quality of starch, which is classified as having the highest grade of purity.

Minerals are inorganic substances present in all tissues. Their presence is essential for the functioning of various key biological processes (Anavi et al., 2013). According to Underwood (1999), potassium is the principle intercellular ion in tissues, essential for muscle tone and activity, a contributor to acid-alkaline 
homeostasis and respiration, via chloride exchange. Comparing Potassium values in the fermentate and tuber (Table 4), the observed significant reduction can be attributed to the extensive washing process that occurred during the starch extraction process.

\section{Film extraction (drying and removal)}

Films of glycerol plastified starch, were homogeneous, continuous, and without fractures or ruptures. On the other hand, cassava-derived films without added glycerol were shown by Shimazu et al. (2007) to be more brittle than those containing glycerol. For films with 1.5 and 2.0 $\mathrm{mL}$ of glycerol (Treatments 4 and 5), which were difficult to detach from the petri dish surfaces without tearing. Mali et al. (2005) consider that the greater adhesion of films is caused by the greater proportion of starch and glycerol in the formulation, thus conferring greater adhesiveness.

\section{Analysis of density, solubility, moisture content, thickness and kinetics}

For 21-day fermentate, only treatment $1(0 \mathrm{~mL}$ of glycerol) differed significantly in thickness from the other four treatments, these being indistinguishable. Such variation in film thickness (Table 3 ) is explained by Ratnayake et al. (2002), who found that glycerol acts by interrupting the formation of an amylose double helix, resulting in shrinkage of the resulting gels and a consequent increase in their thickness. Such results parallel the findings of Liu and Kerry (2005), Matta Júnior et al. (2011), Leyva et al. (2008) and Laohakunjit and Noomhorm (2004) for starch films derived from pinus, pea, wheat and rice respectively. As the filmogenic solution dries, the water evaporates allowing the concentration of the starch to locally increase, so forming an inter-linked network.

For films derived from 14-day fermentate, regression analysis was significant $(p<0.01)$, indicating that when glycerol concentration is increases, the yam-based film becomes thicker (Figure 1). Such results are similar to that of Matta Júnior et al. (2011) on pea-starch films, which showed a linear relationship between glycerol concentration and thickness increase.

For solubility, the studied the biofilms that did not contain glycerol were found to have low solubility due to the loss of water during the drying process, which made them more rigid and brittle. However, as glycerol was added, the films gradually became more soluble reaching an average of $75.57 \%$. This fact is explained by Matta Júnior et al. (2011), Mehyar and Han (2004), Zhang and Han (2006), Leyva et al. (2008), Laohakunji and Noomhorm (2004) and Garcia et al. (2006), who observed that glycerol interacts with the film matrix, increasing the free space between the chains, facilitating the water entry into the film and consequently increasing the solubility.

The humidity of the films showed a significant difference in the interaction between the fermentation time factors and glycerol concentration at $1 \%$ level. According to Chivrac et al. (2010), the relative humidity of storage conditions is an influential factor, since starch tends to absorb large amounts of water in conditions of high relative humidity, due to its hydrophilic nature. This strongly influences its physical and barrier properties (Mali et al., 2005). Regression analysis indicates a tendency for films to increase in humidity as a function of the addition of glycerol. According to Arenas (2012), glycerol content influences the film moisture content because it is hygroscopic, so increasing water content as plasticizer proportion increases.

Similar data have been reported by Shimazu et al. (2007) and Mali et al. (2010) who also found that glycerol favours water absorption. Soares et al. (2016) recorded variations from 9.20 to 23.79 as a function of storage time and $\mathrm{pH}$ concentration, noting that the addition of glycerol increases the absorption of moisture from the environment. Fernandes et al. (2015) reported variations in moisture content of between 42.20 and $84.60 \%$, lower than those found here for yam, for films derived from milk whey.

The difference likely occurs because starch with added plasticizer produces films with high density due to noncomplete gelatinization of the starch at higher glycerol concentrations (Dias, 2008). The density values recorded here are lower than those reported by Müller et al. $(2008)\left(2.41 \mathrm{~g} / \mathrm{cm}^{3}\right)$ for manioc starch films, those of Moore et al. (2006) $\left(0.92\right.$ to $\left.1.10 \mathrm{~g} / \mathrm{cm}^{3}\right)$ for keratinderived films or by Pelissari et al. (2013) $\left(1.34 \mathrm{~g} / \mathrm{cm}^{3}\right)$ for films derived from green banana starch.

Higher sorption kinetics values indicate that a smaller amount of water is being adsorbed, at a reduced rate (Araújo-Farro et al., 2010). The adsorption of moisture was faster in treatments 1 and 2. That smaller amounts of water were adsorbed under treatment 3 , corroborates the data of Mali et al. (2005). According to Galdeano et al. (2014), the glycerol is incorporated into the polymer matrix as it slowly adsorbs the water.

\section{Scanning electron microscope}

The films shown in the photomicrographs in Figures 4 and 5 appear as an extensive and amorphous mass, with the presence of rounded depressions. In this they resemble films studied by de Matta Junior et al. (2011) who stated that such topology may be due to differential drying which results in the presence of non-fully gelatinized and non-fragmented starch granules in the matrix. 
The cross-sectional aspect of the film was similar for all treatments, each having a more homogeneous and a less homogeneous phase, similar to that reported by Batista et al. (2005) and Yang and Paulson (2000) who observed that as glycerol was added the matrix structure became more discontinuous affecting the consistency of the film. Unlike Dantas et al. (2015) who, in starch biofilmes derived from the yellow Guinea yam (Dioscorea cayenensis) reported that the presence of glycerol increased film plasticity by making them more uniform.

The structure of biofilms of treatments 2 and 3 for starch derived from 14-day fermentate (Figure $4 B$ and $C$ ) and those of treatments 1 and 3 (Figure $5 \mathrm{~A}$ and $\mathrm{C}$ ) from 21-day fermentate is similar to those found by AraujoFarro et al. (2010) and Pagno et al. (2015) for quinoaderived biofilms. The compact and uniform structure of these treatments suggests a good interaction between amylose, amylopectin, glycerol and water in the biofilm.

\section{Color}

For the chromatic parameters $a^{*}$ and $b^{*}$, which express the degree of variation between green $(-a)$ and red $(+a)$ and between blue (-b) and yellow $(+b)$, for samples from both 14 and 21 days was a function of the glycerol content of the films. This difference is explained by Silva et al. (2007), who stated that during the gelatinization process of the starch coloration changes occurs due to loss of the initial crystaline structure of the starch granules, so giving the film certain opacity.

\section{Conclusion}

The results of the physico-chemical analysis showed that the samples showed no significant difference in moisture, lipids, titratable acid, fibre, starch and total carbohydrates. Differences were found for ash, protein and $\mathrm{pH}$. Values for ash, starch and titratable acid for the flours manufactured lay within existing legal limits. However, it should be possible to restructure processing methodology so that moisture content is reduced to levels that ensure product stability. For $\mathrm{pH}$, studies are required on the alkaline nature of the samples derived from 21 day fermentate, which differed from the expected. The 21-day fermentate had the best physical-chemical and nutritional profile, and both show an encouraging potential for this product and increased profile for this currently undervalued crop.

The glycerol-free films were more brittle, with the best concentrations being of treatment $2(0.5 \mathrm{~mL}$ glycerol $)$ and $3(1.0 \mathrm{~mL}$ glycerol) in both fermentation periods due to their adherence to the petri dish surface. The thickness and solubility values were best using 14 day fermentation at concentrations of 2.0 and $0.0 \mathrm{~mL}$ of glycerol respectively. However for density, color and water content, the best treatments came from 21-day fermentate.
There were no significant differences for water sorption kinetics by fermentation period. However, adding plasticizer influenced this parameter significantly. Scanning electron microscopy showed that the starch without added glycerol has the most homogeneous matrix; as the glycerol is added, some starch granules will be present that have not been fully dissolved.

\section{CONFLICT OF INTERESTS}

The authors have not declared any conflict of interests.

\section{ACKNOWLEDGMENTS}

The authors would like to thank the Laboratory of Food Chemistry and Physics of the National Institute of Amazonian Research, the Graduate Program in Agriculture in the Humid Tropics (PPG-ATU), the State University Complex of Research Support Centers (COMCAP) from Maringá, the Laboratory of Technological Innovation in the Development of Pharmaceuticals and Cosmetics, the Food and Nutrition Security Center of the Federal University of Amazonas (UFAM) and the Foundation for Support to the Amazon Research Foundation (FAPEAM). Amazon State Survey) for financial support (concession 062.01725 / 2014 PAPAC and 062.00682 / 2015 Universal). Adrian Barnett helped with the English

\section{REFERENCES}

Aquino ACMS, Santos JC, Castro AA, Silva GF (2011). Caracterização físico-química e microbiológica de farinhas de inhame durante o armazenamento em diferentes embalagens. Scientia Plena. Available at: https://www.scientiaplena.org.br/ sp/article/view/161/210

Aquino ACMS, Gervin VM, Amante ER (2016). Avaliação do processo produtivo de polvilho azedo em indústrias de Santa Catarina. Brazilian Journal of Food Technology 19(19):1-8.

Almeida DM, Woiciechowski AL, Wosiacki G, Prestes RA, Pinheiro LA (2013). Propriedades físicas, químicas e de barreira em filmes formados por blenda de celulose bacteriana e fécula de batata. Polímeros 23(4):538-546.

Almeida LBS (2014). Propriedades físicas e antimicrobianas do filme e do revestimento comestível de quitosana e galactomanana de 'Adenanthera pavonina' L. (Master's dissertation). Universidade Federal do Ceará, Fortaleza.

Alves A, Cansian RL, Stuart G, Valduga E (2005). Alterações na qualidade de raízes de mandioca (Manihot esculenta Crantz) minimamente processadas. Ciência e Agrotecnologia 29(2):330-337.

Anavi S, Imas P, Wilendl T (2013). Nutrição e saúde: a importância do Potássio. International Potash Institute. Available at: https://www.ipipotash.org/

Araujo-Farro PC, Podadera G, Sobral PJA, Menegalli FC (2010). Development of films based on quinoa (Chenopodium quinoa Willdenow) starch. Carbohydrate Polymers 81(4):839-848.

Arenas AMZ (2012). Filme biodegradável à base de fécula de mandioca como potencial indicador de mudança de $\mathrm{pH}$ (Master's dissertation), Universidade de São Paulo, São Paulo.

Ascheri DPR, Vilela ER (1995). Alterações do polvilho da mandioca pela fermentação, no fabrico de biscoitos. Pesquisa Agropecuária Brasileira. Available at: 
https://seer.sct.embrapa.br/index.php/pab/article/view/4302/1588

Association of Official Analytical Chemists (AOAC) (1980). Official methods of analysis. (13 ed.). Washington, District of Columbia: USA. $1040 \mathrm{p}$.

Batista JA, Tanada-Palmu PS, Grosso CRF (2005). Efeito da adição de ácidos graxos em filmes à base de pectina. Ciência e Tecnologia de Alimentos 25(4):781-788.

Brazil. Agência Nacional de Vigilância Sanitária (ANVISA) (2005). Resolução RDC n. 263 de 22 de setembro de 2005. Available at: http://bvsms.saude.gov.br/bvs/ saudelegis/anvisa/2005/rdc0263 2209 2005.html

BRAsIL. Decreto no 12.486, de 20 de outubro de (1978). Normas técnicas especiais relativas a alimentos e bebidas. Available at: https://www.al.sp.gov.br/repositorio/ legislacao/decreto/1978/decreto12486-20.10.1978. html

Cano A, Jiménez A, Cháfer M, Gónzalez C, Chiralt A (2014). Effect of amylose: amylopectin ratio and rice bran addition on starch films properties. Carbohydrate Polymers 111(13):543-555.

Cereda MP, Franco CML, Daiuto ER, Demiate IM, Carvalho LJB, Leonel M, Vilpoux OF, Sarmento SBS (2001). Propriedades gerais do amido. São Paulo, SP: Fundação Cargill. 224 p.

Cereda MP, Vilpoux OF (2003). Tecnologias, usos e potencialidades de tuberosas amiláceas latino americanas. São Paulo, SP: Fundação Cargill $771 \mathrm{p}$.

Cereda MP (1987). Tecnologia e qualidade do polvilho azedo. Informe Agropecuário. Available at: https://www.researchgate.net/publication/285222600_Tecnologia_e_ qualidade do polvilho azedo

Cereda MP, Lima VA (1981). Aspectos sobre a fermentação da fécula de mandioca. Sociedade Brasileira de Ciência e Tecnologia de Alimentos. Available

at: http://www.fealq.org.br/ojs/index.php/revistadeagricultura/article/view/ 383/pdf_58.

Chivrac F, Pollet E, Dole P, Avérous L (2010). Starch-based nanobiocomposites: plasticizer impact on the montmorillonite exfoliation process. Carbohydrate Polymers 79(4):941-947.

Coles R (2003). Food packaging technology. Oxford, UK: Blackwell publishing $346 \mathrm{p}$.

Dantas EA, Costa SS, Cruz LS, Bradmont WB, Costa AS, Padilha FF, Druzian JI, Machado BAS (2015). Caracterização e avaliação das propriedades antioxidantes de filmes biodegradáveis incorporados com polpas de frutas tropicais. Ciência Rural 45(1):142-148.

Dantas AGM, Paulo JLA, Guerra MG, Freitas MO (2010). Análises bromatológicas de onze cultivares de mandioca. Revista Caatinga 23(3):130-136.

Daiuto ER, Cereda MP (2003). Tecnologia, usos e potencialidades de tuberosas amiláceas Latino Americanas. São Paulo, SP: Fundação Cargill. $771 \mathrm{p}$.

Dias AB (2008). Desenvolvimento e caracterização de filmes biodegradáveis obtidos de amido e de farinha de arroz (Master's dissertation), Universidade Federal de Santa Catarina, Rio Grande do Sul.

Dias LT, Leonel M (2006). Caracterização físico-química de farinhas de mandioca de diferentes localidades do Brasil. Ciência e Agrotecnologia 40(4):692-700.

Diniz IR (2006). Caracterização tecnológica do polvilho azedo produzido em diferentes regiões do estado de Minas Gerais. (Master's dissertation), Universidade Federal de Viçosa, Minas Gerais.

Ferreira PP (2014). Extração, caracterização e aplicação de fécula de açafrão (Curcuma longa L.) no desenvolvimento de biscoito. (Master's dissertation), Universidade Federal de Goiás, Goiânia.

Fernandes APS, Costa JB, Soares DSB, Moura CJ, Souza ARM (2015). Aplicação de filmes biodegradáveis produzidos a partir de concentrado proteico de soro de leite irradiado. Pesquisa Agropecuária Tropical 45(2):192-199.

Fiorda FA, Soares Júnior MS, Silva FA, Souto LRF, Grossmann MVE (2013). Farinha de bagaço de mandioca: aproveitamento de subproduto e comparação com fécula de mandioca. Pesquisa Agropecuária Tropical 43(4):408-416.

Galdeano MC, Wilhelm AE, Grossmann MVE, Mali S (2014). Efeito do processamento e das condições ambientais nas propriedades de materiais biodegradáveis de amido de aveia. Polímeros 24(1):80-87.

Garcia MA, Pinotti A, Zaritzky NE (2006). Physicochemical, water vapor barrier and mechanical properties of starch and chitosan composite films. Starch 58(9):453-463.

Garcia MC, Franco CML, Soares Júnior MS, Caliari M (2014). Características estruturais e propriedades de gelatinização de polvilho azedo. Available at: https://docplayer.com.br/46894557Caracteristicas-estruturais-e-propriedades-de-gelatin izacao-depolvilho-azedo.html.

Holland N, Oliveira JJO (2015). Composição centesimal e amido resistente de goma de mandioca e tapioca. Available at: https:/proceedings.science/slaca/slaca-2015/ trabalhos/composicaocentesimal-e-amido-resistente-de-goma-de-mandioca-e-tapioca.

Hunterlab (1997). Manual version 1.5. Virginia, USA: Reston. 80 p.

Instituto Adolfo Lutz (IAL) (2008). Normas analíticas do Instituto Adolfo Lutz: métodos químicos e físicos para análise de alimentos. São Paulo, SP: Instituto Adolfo Lutz. 1020 p.

Ladeira TMS, Pena RS (2011). Propriedades físico-químicas e tecnológicas dos polvilhos azedos de três cultivares de mandioca. Alimentos e Nutrição 22(4):631-640.

Laohakunjit N, Noomhorm A (2004). Effect of plasticizer on mechanical and barrier properties of rice starch film. Starch 56(8):348-356.

Leonel M, Cereda MP (2002). Caracterização físico-química de algumas tuberosas amiláceas. Ciência e Tecnologia de Alimentos 22(1):65-69.

Leonel M, Garcia ACDB, Reis MM (2004). Caracterização físicoquímica e microscópica de amidos de batata-doce, biri, mandioca e taioba e propriedades de expansão após modificação fotoquímica. Brazilian Journal of Food Technology 7(2):129-137.

Leyva MB, Chávez PT, Wong BR, Jatomea MP, Bojórquez FB (2008). Physical an mechanical properties of durum wheat (Triticum durum) starch films prepared with a and b type granules. Starch 60(10):559567

Liu Z, Kerry JH (2005). Film-forming characteristics of starch. Journal of Food Science 70(1):31-36.

Lorotonda FDS (2002). Desenvolvimento de biofilmes a partir da fécula de mandioca. (Master'sdissertation), Universidade Federal de Santa Catarina, Rio Grande do Sul.

Luna AT, Rodrigues FFG, Costa JGM, Pereira AOB (2013). Estudo físico-químico, Bromatológico e Microbiológico de Manihot esculenta Crantz (Mandioca). Revista Interfaces: Saúde, Humanas e Tecnologia 1(2):1-11.

Machado ACSDV, Diniz IP, Teixeira MAV, Birchal VS (2013). Estudo do efeito da secagem por radiação ultravioleta nas propriedades tecnológicas da fécula de mandioca fermentada. E-xacta 5(1):7-14.

Machado AV, Araújo FMMC, Pereira J (2010). Caracterização física, química e tecnológica do polvilho azedo. Revista Verde de Agroecologia e Desenvolvimento Sustentável 5(3):1-6.

Maeda KC (1999). Proposta de classificação para o polvilho azedo. (Master's dissertation), Universidade de São Paulo, São Paulo.

Maieves HA (2010). Caracterização Física, Físico Química e Potencial Tecnológicode novas Cultivares de Mandioca. (Master's dissertation), Universidade Federal de Santa Catarina, Florianópolis.

Mali S, Sakanaka LS, Yamashita F, Grossmann MVE (2005). Water sorption and mechanical properties of cassava starch films and their relation to plasticizing effect. Carbohydrate Polymers 60(3):283-289.

Mali S, Grossmann MVE, Yamashita F (2010). Filmes de amido: produção, propriedades e potencial de utilização. Semina: Ciências Agrárias 31(1):137-156.

Marcon MJA, Vieira MA, Santos K, Simas KN, Amboni RDMC, Amante ER (2006). The effect of fermentation on cassava starch microstructure. Journal of Food Process Engineering 29(4):362-372.

Matta Júnior MD, Sarmento SBS, Sarantópoulos CIGL, Zocchi SS (2011). Propriedades de Barreira e Solubilidade de Filmes de Amido de Ervilha Associado com Goma Xantana e Glicerol. Polímeros 21(1):67-72.

Mattos LL, Martins IS (2000). Consumo de fibras alimentares em população adulta. Revista de Saúde Pública 34(1):50-55.

Mehyar GF, Han JH (2004). Physical and mechanical properties of high-amylose rice and pea starch films a effected by relative humidity and plasticizer. Journal of Food Science 69(9):449-454.

Moore GRP, Martelli SM, Gandolfo C, Sobral PJA, Laurindo JB (2006). 
Influence of the glycerol concentration on some physical properties of feather keratin films. Food Hydrocolloids 20(7):975-982.

Müller C, Yamashita F, Laurindo JB (2008). Evaluation of effects of glycerol and sorbitol concentration and water activity on the water barrier properties of cassava starch films through a solubility approach. Carbohydrate Polymers 72(1):82-87.

Nascimento KO, Rocha DGCM, Silva EB, Barbosa Júnior JL, Nascimento MIMJBO (2013). Caracterização química e informação nutricional de fécula de batata-doce (Ipomoea batatas L.) orgânica e biofortificada. Revista Verde de Agroecologia e Desenvolvimento Sustentável 8(1):132-138.

Nunes LS, Duarte MEM, Mata MERMC, Almeida RD, Gouveia DS (2010). Comportamento reológico de pasta de amido de inhame variedade São Tomé. Revista Brasileira de Produtos Agroindustriais 12(2):141-154.

Oliveira AP (2002). Nutrição e época de colheita do inhame (Dioscorea sp.) e seus reflexos na produção e qualidade de rizóforos. Available at: https://www.fepeg2016.unimontes.br/index.php/anais/ver/2360.

Oliveira DC (2011). Caracterização e potencial tecnológico de amidos de diferentes cultivares de mandioca (Manihot esculenta Crantz). (Master's dissertation), Universidade Federal de Santa Catarina, Rio Grande do Sul.

Pagno $\mathrm{CH}$, Costa TMH, Costa TMH, Menezes EW, Benvenutti EV, Hertz P F, Matte CR, Tosati JV, Monteiro AR, Rios AO, Flôres SH (2015). Development of active biofilmes of quinoa (Chenopodium quinoa W.) starch containing gold nanoparticles and evaluation of antimicrobial activity. Food Chermistry 173:755-762.

Pelissari FM, Andrade-Mahecha MM, Sobral PJA, Menegalli FC (2013). Comparative study on the properties of flour and starch films of plantain banana (Musa paradisiaca). Food Hydrocolloids 30(2):681690.

Pereda M, Ponce AG, Marcovich NE, Martucci JF (2011). Chitosangelatin composites and bi-layer films with potential antimicrobial activity. Food Hydrocolloids 25(5):1372-1381.

Pereira J, Ciacco CF, Vilela ER, Teixeira ALS (1999). Féculas fermentadas na fabricação de biscoitos: estudo de fontes alternativas. Revista Ciência e Tecnologia de Alimentos 19(2):287293.

Peroni FHG (2003). Características estruturais e físico-químicas de amidos obtidos de diferentes fontes botânicas. (Master's dissertation), Universidade Estadual Paulista, São Paulo.

Ratnayake WS, Hoover R, Warkentin T (2002). Pea starch: composition, structure and properties - A review. Starch 54(6):217234.

Reginatto V, Kurtz D, Marcon MJA, Xavier JJM, Scussel VM, Amante ER (2009). Modificação do processo de produção de polvilho azedo visando o aumento na concentração de ácidos orgânicos na água residuária. Available

at: http://www.advancesincleanerproduction.net/second/files/sessoes/6a/ 7/V.\%20Reginatto\%20-\%20Resumo\%20Exp\%20-\%206A-7.pdf.

Reis LCB (2011). Formulação e caracterização de filmes biodegradáveis de fécula de mandioca incorporados com polpa de manga e extrato de erva-mate, e seu efeito na preservação de alimentos. (Master's dissertation). Universidade Federal da Bahia, Salvador.

Reis RC, Sérvulo ACO, Souza ABM, Devilla IA, Ascheri DPR, Colares CJG, Barbosa LB (2010). Características Centesimais do amido de inhame (Dioscorea sp.). Available at: http://www.prp.ueg.br/conteudo/2555_seminario_de_ic.

Rocha DA, Abreu CMP, Sousa RV, Corrêa AD (2012). Método de obtenção e análise da composição centesimal do polvilho da frutade-lobo (Solanum lycocarpum ST. HIL). Revista Brasileira de Fruticultura 34(1):248-254.
Santos TA (2015). Desenvolvimento e caracterização de bioplásticos a base de amido de jaca com incorporação de lisozima. (Master's dissertation). Universidade Estadual do Sudoeste da Bahia, Itapetinga.

Shimazu AA, Mali S, Grossmann MVE (2007). Plasticizing and antiplasticizing effects of glycerol and sorbitol on biodegradable cassava starch films. Semina: Ciências Agrárias 28(1):79-88.

Silva PA, Melo WS, Cunha RL, Cunha EFM, Lopes AS, Pena RS (2012). Obtenção e caracterização das féculas de três variedades de mandioca produzidas no Estado do Pará. Available at: https://ainfo.cnptia.embrapa.br/digital/bitstream/item/79074/1/AnaisFecula-silva.pdf.

Silva GO, Takizawa FF, Pedroso RA, Franco CML, Leonel M, Sarmento SBS, Demiate IM (2006). Características físico-químicas de amidos modificados de grau alimentício comercializados no Brasil. Ciência e Tecnologia de Alimentos 26(1):188-197.

Silva WA, Pereira J, Carvalho CWP, Ferreira FQ (2007). Determinação da cor, imagem superficial topográfica e ângulo de contato de biofilmes de diferentes fontes de amido. Ciência e Agrotecnologia 31(1):154-163.

Soares DSB, Silva EEAN, Oliveira TM (2016). Aplicação de filmes biodegradáveis de proteína de soro de leite. Revista de Agricultura Neotropical 3(3):1-5.

Trombini FRM, Leonel M, Mischan MM (2013). Desenvolvimento de snacks extrusados a partir de misturas de farinha de soja, fécula e farelo de mandioca. Ciência Rural 43(1):178-184.

Tupinamba L, Souza F (2010). Caracterização físico-química e análise sensorial da farinha de mandioca seca (Manihot esculenta Crantz) enriquecida com semente de linhaça marrom (Linum usiotatissum L.). Available at: https://interfaces. leaosampaio.edu.br/index. php/revistainterfaces/article/viewFile/15/20

Underwood EJM (1999). The mineral nutrition of livestock. Wallingford, UK: CABI Publishing $579 \mathrm{p}$.

Varian (2000). Spectra AA, 50/55/110/220: Manual do Fabricante. Available at: http://photos.labwrench.com/equipmentManuals/170606201.pdf.

Vieira JC, Montenegro FM, Lopes AS, Pena RS (2010). Influência da adição de fécula de mandioca nas características do pão tipo chá. Ceppa 28(1):37-48.

Vilpoux O, Cereda MP, Franco CML, Leonel M, Sarmento SS, Daiuto ER, Guerreiro LM, Oliveira M (2002). Relatório do projeto temático: Prospecção de novos amidos para indústria de alimentos. Available

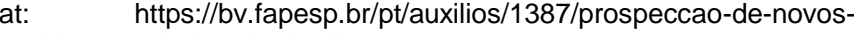
amidos-para-industria-de-alimentos.

Water M, Silva LP, Perdomo DMX (2005). Amido disponível e resistente: adaptação do método da AOAC 996.11. Revista Alimentos e Nutrição 16(1):39-43.

Yang L, Paulson AT (2000). Effects of lipids on mechanical and moisture barrier properties of edible gellan film. Food Research International 33(7):571-578.

Zhang Y, Han JH (2006). Mechanical and thermal characteristics of pea starch fims plasticized with monosaccharides and polyols. Journal of Food Science 71(2):109-118. 